\title{
Charcot-Marie-Tooth disease type 2B1
}

INSERM

\section{Source}

INSERM. (1999). Orphanet: an online rare disease and orphan drug data base. CharcotMarie-Tooth disease type 2B1. ORPHA:98856

Charcot-Marie-Tooth disease, type 2B1 (CMT2B1, also referred to as CMT4C1) is an axonal CMT peripheral sensorimotor polyneuropathy. 